\title{
Front Matter: Volume 7857
}

, "Front Matter: Volume 7857," Proc. SPIE 7857, Multispectral, Hyperspectral, and Ultraspectral Remote Sensing Technology, Techniques, and Applications III, 785701 (23 November 2010); doi: 10.1117/12.885249

SPIE. Event: SPIE Asia-Pacific Remote Sensing, 2010, Incheon, Korea, Republic of 


\title{
PROCEEDINGS OF SPIE
}

\section{Multispectral, Hyperspectral, and Ultraspectral Remote Sensing Technology, Techniques, and Applications III}

\author{
Allen M. Larar \\ Hyo-Sang Chung \\ Makoto Suzuki \\ Editors \\ 13-14 October 2010 \\ Incheon, Korea, Republic of \\ Sponsored by \\ SPIE \\ Cosponsored by \\ Korea Ocean Research \& Development Institute (Korea, Republic of) \\ Korea Ocean Satellite Center (Korea, Republic of) \\ Ministry of Land, Transport and Maritime Affairs (Korea, Republic of) \\ Incheon Metropolitan City (Korea, Republic of) \\ Incheon Tourism Organization (Korea, Republic of) \\ National Aeronautics and Space Administration (United States) \\ National Institute of Information and Communications Technology (Japan) \\ Science Technology Corporation (United States) \\ Indian Space Research Organization (India) \\ Indian National Centre for Ocean Information Services (India) \\ Published by \\ SPIE
}

Volume 7857 
The papers included in this volume were part of the technical conference cited on the cover and title page. Papers were selected and subject to review by the editors and conference program committee. Some conference presentations may not be available for publication. The papers published in these proceedings reflect the work and thoughts of the authors and are published herein as submitted. The publisher is not responsible for the validity of the information or for any outcomes resulting from reliance thereon.

Please use the following format to cite material from this book:

Author(s), "Title of Paper," in Multispectral, Hyperspectral, and Ultraspectral Remote Sensing Technology, Techniques, and Applications III, edited by Allen M. Larar, Hyo-Sang Chung, Makoto Suzuki, Proceedings of SPIE Vol. 7857 (SPIE, Bellingham, WA, 2010) Article CID Number.

ISSN 0277-786X

ISBN 9780819483874

Published by

SPIE

P.O. Box 10, Bellingham, Washington $98227-0010$ USA

Telephone +1 3606763290 (Pacific Time) · Fax +1 3606471445

SPIE.org

Copyright (C) 2010, Society of Photo-Optical Instrumentation Engineers

Copying of material in this book for internal or personal use, or for the internal or personal use of specific clients, beyond the fair use provisions granted by the U.S. Copyright Law is authorized by SPIE subject to payment of copying fees. The Transactional Reporting Service base fee for this volume is $\$ 18.00$ per article (or portion thereof), which should be paid directly to the Copyright Clearance Center (CCC), 222 Rosewood Drive, Danvers, MA 01923. Payment may also be made electronically through CCC Online at copyright.com. Other copying for republication, resale, advertising or promotion, or any form of systematic or multiple reproduction of any material in this book is prohibited except with permission in writing from the publisher. The CCC fee code is 0277-786X/10/\$18.00.

Printed in the United States of America.

Publication of record for individual papers is online in the SPIE Digital Library.

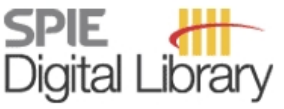

SPIEDigitalLibrary.org

Paper Numbering: Proceedings of SPIE follow an e-First publication model, with papers published first online and then in print and on CD-ROM. Papers are published as they are submitted and meet publication criteria. A unique, consistent, permanent citation identifier (CID) number is assigned to each article at the time of the first publication. Utilization of CIDs allows articles to be fully citable as soon they are published online, and connects the same identifier to all online, print, and electronic versions of the publication. SPIE uses a six-digit CID article numbering system in which:

- The first four digits correspond to the SPIE volume number.

- The last two digits indicate publication order within the volume using a Base 36 numbering system employing both numerals and letters. These two-number sets start with 00, 01, 02, 03, 04 , 05, 06, 07, 08, 09, OA, OB ... 0Z, followed by 10-1Z, 20-2Z, etc.

The CID number appears on each page of the manuscript. The complete citation is used on the first page, and an abbreviated version on subsequent pages. Numbers in the index correspond to the last two digits of the six-digit CID number. 


\title{
Contents
}

\author{
ix Symposium Committees \\ $\mathrm{xi}$ Conference Committee \\ xiii Introduction
}

SESSION 1 ATMOSPHERIC SOUNDING, RETRIEVALS, AND INFORMATION CONTENT

785702 Eight years of AIRS (Invited Paper) [7857-01]

S.-Y. Lee, T. Pagano, M. Chahine, E. Fetzer, Jet Propulsion Lab. (United States)

785703 IR ultraspectral remote sensing: efficient physical-statistical nonlinear sounding retrieval algorithms [7857-02]

W. Smith, Sr., Univ. of Wisconsin-Madison (United States) and Hampton Univ. (United States);

S. Kireev, Hampton Univ. (United States); E. Weisz, Univ. of Wisconsin-Madison (United States); Y. Jian, M. Yesalusky, Hampton Univ. (United States); A. Larar, NASA Langley Research Ctr. (United States); H. Revercomb, Univ. of Wisconsin-Madison (United States)

785704 How well can infrared sounders observe the atmosphere and surface through clouds? [7857-03]

D. K. Zhou, A. M. Larar, X. Liu, NASA Langley Research Ctr. (United States); W. L. Smith, Hampton Univ. (United States) and Univ. of Wisconsin-Madison (United States); L. L. Strow, Univ. of Maryland, Baltimore County (United States); P. Yang, Texas A\&M Univ. (United States)

785705 Porting and testing NPOESS CrIMSS EDR algorithms [7857-04]

X. Liu, NASA Langley Research Ctr. (United States); S. Kizer, Science Systems and Applications, Inc. (United States); A. Larar, NASA Langley Research Ctr. (United States); D. Zhou, Science Systems and Applications, Inc. (United States); W. Smith, Hampton Univ. (United States); C. Barnet, NOAA Ctr. for Satellite Applications (United States); M. Divakarla, IM Systems Group, Inc. (United States); G. Guo, PSGS (United States); B. Blackwell, V. Leslie, L. Jairam, MIT Lincoln Lab. (United States); K. St. Germain, NOAA NPOESS Integrated Program Office (United States); R. Lynch, Atmospheric and Environmental Research, Inc. (United States)

785706 Spectral resolution and coverage impact on advanced sounder information content [7857-05]

A. M. Larar, X. Liu, D. K. Zhou, NASA Langley Research Ctr. (United States); W. L. Smith, Hampton Univ. (United States) and Univ. of Wisconsin-Madison (United States)

785708 Retrieval of minor constituents from thermal infrared spectra observed by GOSAT TANSO-FTS sensor [7857-07]

R. Imasu, Y. Hayashi, A. Inagoya, The Univ. of Tokyo (Japan); N. Saitoh, Chiba Univ. (Japan);

K. Shiomi, Japan Aerospace Exploration Agency (Japan) 
785709 Aerosol optical properties derived from solar spectrum measurements and their application to atmospheric correction of satellite data [7857-08]

N. Manago, S. Miyazawa, K. Kuriyama, H. Kuze, Chiba Univ. (Japan)

\section{SESSION 2 DATA PROCESSING, COMPRESSION, AND FUSION}

7857 OB Preprocessing of hyperspectral imagery with consideration of smile and keystone properties [7857-10]

N. Yokoya, N. Miyamura, A. Iwasaki, The Univ. of Tokyo (Japan)

7857 OC Fast compression implementation for hyperspectral sensor [7857-12]

H. Hihara, J. Yoshida, J. Ishida, NEC TOSHIBA Space Systems, Ltd. (Japan); J. Takada, NEC Information Systems Ltd. (Japan); Y. Senda, NEC Corp. (Japan); M. Suzuki, T. Seki, S. Ichikawa, Japan Aerospace Exploration Agency (Japan); N. Ohgi, Japan Resource Observation System and Space Utilization Organization (Japan)

\section{SESSION 3 REMOTE SENSING AIR QUALITY APPLICATIONS}

7857 OF Application of THEOS for PM10 mapping over Penang Island, Malaysia [7857-15]

H. S. Lim, M. Z. MatJafri, K. Abdullah, Univ. Sains Malaysia (Malaysia)

7857 OG Performance of satellite regional bio-optical algorithms depending on relationships between chlorophyll-a and dissolved organic matter concentrations [7857-16] O. A. Bukin, Maritime State Univ. (Russian Federation); P. A. Salyuk, V.I. Il'ichev Pacific Oceanological Institute (Russian Federation); A. N. Pavlov, Institute for Automation and Control Processes (Russian Federation); I. Stepochkin, Maritime State Univ. (Russian Federation); I. A. Golik, V.I. Il'ichev Pacific Oceanological Institute (Russian Federation)

$7857 \mathrm{OH} \quad$ Tuning of hyperspectral bio-optical algorithms in the Peter the Great Bay [7857-17] P. A. Salyuk, V.I. Il'ichev Pacific Oceanological Institute (Russian Federation); O. A. Bukin, I. E. Stepochkin, Maritime State Univ. (Russian Federation); V. A. Krikun, V.I. Il'ichev Pacific Oceanological Institute (Russian Federation); A. N. Pavlov, Institute for Automation and Control Processes (Russian Federation)

\section{SESSION 4 FUTURE SENSORS: CALIBRATION AND SENSOR DESIGN}

7857 0J On-orbit absolute temperature calibration using multiple phase change materials: overview of recent technology advancements [7857-19]

F. A. Best, D. P. Adler, C. Pettersen, H. E. Revercomb, J. H. Perepezko, Univ. of WisconsinMadison (United States)

7857 OK The University of Wisconsin Space Science and Engineering Center Absolute Radiance Interferometer (ARI) [7857-20]

J. K. Taylor, H. E. Revercomb, Univ. of Wisconsin-Madison (United States); H. Buijs,

F. J. Grandmont, ABB-Bomem Inc. (Canada); P. J. Gero, F. A. Best, D. C. Tobin,

R. O. Knuteson, D. D. LaPorte, R. Cline, M. Schwarz, J. Wong, Univ. of Wisconsin-Madison (United States) 
$7857 \mathrm{OL}$ On-orbit absolute blackbody emissivity determination using the heated halo method [7857-21]

P. J. Gero, J. K. Taylor, F. A. Best, H. E. Revercomb, R. O. Knuteson, D. C. Tobin, D. P. Adler, N. N. Ciganovich, S. Dutcher, R. K. Garcia, Univ. of Wisconsin-Madison (United States)

$7857 \mathrm{OM}$ The functional evaluation model for the on-board hyperspectral radiometer [7857-22]

T. Kawashima, Y. Narimatsu, H. Inada, NEC Corp. (Japan); J. Ishida, K. Hamada, Y. Ito, J. Yoshida, NEC TOSHIBA Space Systems, Ltd. (Japan); N. Ohgi, K. Tatsumi, H. Harada, T. Kawanishi, F. Sakuma, Japan Resources Observation System and Space Utilization Organization (Japan); A. Iwasaki, The Univ. of Tokyo (Japan)

7857 ON Design and applications of space-borne imaging spectrometer based on acousto-optic tunable filter (AOTF) [7857-23]

J. Wang, Z. He, R. Shu, Shanghai Institute of Technical Physics (China)

785700 Hyperspectral and multispectral sensors for remote sensing [7857-24]

J. Miller, S. Kullar, D. Cochrane, N. O, A. Lomako, C. Draijer, DALSA Corp. (Canada)

\section{SESSION 5 REMOTE SENSING LAND APPLICATIONS}

$78570 Q \quad$ Remotely based monitoring of the mangroves over Penang Island, Malaysia [7857-27]

B. C. Beh, M. Z. MatJafri, H. S. Lim, Univ. Sains Malaysia (Malaysia)

7857 OS Performances of frequency-based contextual classifier in land use/cover classification using high resolution satellite images [7857-35]

M. R. Mustapha, H. S. Lim, M. Z. MatJafri, F. M. Hassan, Univ. Sains Malaysia (Malaysia)

POSTER SESSION

7857 OT Enhancing remote sensing images by adjusting histogram globally and locally [7857-31]

F. Chen, X. Li, F. Li, J. Liu, J. Yang, Ctr. for Earth Observation and Digital Earth (China)

7857 OU Pixel discontinuity handling of ortho-rectification images for airborne pushbroom imager [7857-32]

J.-Y. Lai, M.-F. Chen, T.-H. Wei, C.-Y. Chan, T.-M. Huang, Instrument Technology Research Ctr. (Taiwan)

7857 OW Defective CCDs detection and image restoration based on inter-band radiance interpolation for hyperspectral imager [7857-36]

M.-F. Chen, J.-Y. Lai, L.-J. Lee, T.-M. Huang, Instrument Technology Research Ctr. (Taiwan)

7857 0X Simulation of spectral effects of Asian dusts on the AIRS radiances and its application to retrieval of dust properties [7857-37]

H.-J. Han, B.-J. Sohn, Seoul National Univ. (Korea, Republic of); H.-L. Huang, E. Weisz, Univ. of Wisconsin-Madison (United States) 
7857 OY Remote sensing image classification method based on evidence theory and decision tree [7857-38]

X. Li, Graduate Univ. of the Chinese Academy of Sciences (China) and Yantai Institute of Coastal Zone Research (China); Q. Xing, Yantai Institute of Coastal Zone Research (China); L. Kang, Graduate Univ. of the Chinese Academy of Sciences (China) and Yantai Institute of Coastal Zone Research (China)

785710 Effects of $\mathbf{N}$ fertilization on the relationship between photosynthetic light use efficiency and photochemical reflectance index of wetland vegetation [7857-41]

Q. Cheng, X. Wu, Zhejiang Gongshang Univ. (China)

785712 Key technologies of land use information extraction based upon multisource remote sensing data: a case study of hilly-plain transition region in the middle and lower reaches of the Yellow River [7857-43]

H. Lu, Henan Univ. (China) and United Nations Univ. (Japan); G. Liu, Henan Univ. (China)

785713 Pose parameter extraction of corn canopy remote sensing images based on parallel multi-ocular imaging [7857-44]

X. Li, Heilongjiang Bayi Agriculture Univ. (China); Y. Zhang, China Agricultural Univ. (China); J. Zhu, Heilongjiang Bayi Agriculture Univ. (China); R. Zhao, M. Li, China Agricultural Univ. (China)

785714 Evaluation of land use classification accuracy based upon TM and CBERS-02B HR data fusion [7857-45]

G. Liu, Henan Univ. (China); H. Lu, Henan Univ. (China) and United Nations Univ. (Japan)

785715 Predicting chlorophyll content of greenhouse tomato with ground-based remote sensing [7857-46]

Y. Ding, China Agricultural Univ. (China) and Lanzhou City Univ. (China); M. Li, S. Li, D. An, China Agricultural Univ. (China)

785716 Study on the spectral characteristics of the damaged rice under brown planthopper, Nilaparvata lugens [7857-47]

X. WU, Q. Cheng, Zhejiang Gongshang Univ. (China)

785717 Mixed-spectrum generation mechanism analysis of dispersive hyperspectral imaging for improving environmental monitoring of coastal waters [7857-48]

F. Xie, G. Xiao, H. Qi, R. Shu, J. Wang, Y. Xue, Shanghai Institute of Technical Physics (China)

785719 Variable rate fertilization based on spectral index and remote sensing [7857-50]

S. Li, M. Li, Y. Ding, R. Zhao, China Agricultural Univ. (China)

7857 1A Study on space-borne LWIR FPA imaging system [7857-51]

C. Li, Y. Liu, J. Wang, Shanghai Institute of Technical Physics (China)

7857 1B Aerosol optical thickness retrieval by using a handheld spectroradiometer over Penang Island, Malaysia [7857-52]

H. S. Lim, M. Z. MatJafri, K. Abdullah, N. M. Saleh, Univ. Sains Malaysia (Malaysia) 
$7857 \mathrm{IE}$ Research on the sequential images registration of the temporally and spatially modulated Fourier transform imaging spectrometer [7857-55]

X. Zhang, Q. Wang, Beijing Univ. of Aeronautics \& Astronautics (China); Z. Zhou, Univ. of Science and Technology of China (China); C. Sun, Beijing Univ. of Aeronautics \& Astronautics (China)

$7857 \mathrm{iF}$ Land cover mapping based on a frequency based contextual classifier from remote sensing data over Penang Island, Malaysia [7857-56]

H. S. Lim, M. Z. MatJafri, K. Abdullah, Univ. Sains Malaysia (Malaysia)

7857 IG Winter wheat nutrition diagnosis under different $\mathbf{N}$ treatments based on multispectral images and remote sensing [7857-57]

R. Zhao, M. Li, S. Li, Y. Ding, China Agricultural Univ. (China)

$7857 \mathrm{1H}$ Assessment of ALOS PALSAR data for land cover/land use mapping in Malaysia [7857-58]

C. K. Sim, K. Abdullah, M. Z. MatJafri, H. S. Lim, Univ. Sains Malaysia (Malaysia)

7857 IK A hyperspectral imager with adjustable spectral selectivity based on AOTF [7857-61] J. Liu, R. Shu, Y. Ma, J. Wang, Shanghai Institute of Technical Physics (China)

7857 IL E-AERI calibration performance certification [7857-62]

R. Knuteson, F. Best, N. Ciganovich, R. Garcia, D. Hackel, H. Revercomb, J. Taylor, D. Turner, Univ. of Wisconsin-Madison (United States)

7857 1M Spectral feature extraction and modeling of soil total nitrogen content based on NIR technology and wavelet packet analysis [7857-63]

L. Zheng, M. Li, X. An, L. Pan, H. Sun, China Agricultural Univ. (China)

785710 Research on the classification of karst rocky desertification based on hyperspectral remote sensing images [7857-65]

K. Zhu, Y. An, Y. Zhang, Guizhou Normal Univ. (China)

Author Index 
Downloaded From: https://www.spiedigitallibrary.org/conference-proceedings-of-spie on 26 Apr 2023

Terms of Use: https://www.spiedigitallibrary.org/terms-of-use 


\title{
Symposium Committees
}

\author{
Symposium General Chairs
}

Upendra N. Singh, NASA Langley Research Center (United States)

Yu-Hwan Ahn, Korea Ocean Research \& Development Institute (Korea, Republic of)

Symposium General Cochairs

Toshio Iguchi, National Institute of Information and Communications Technology (Japan)

A. S. Kiran Kumar, Space Applications Center (India)

Delu Pan, State Oceanic Administration (China)

Symposium Honorary Chairs

Michael Freilich, NASA Headquarters (United States)

Mary Ellen Kicza, National Oceanic and Atmospheric Administration (United States)

Takashi Moriyama, Japan Aerospace Exploration Agency (Japan)

Ranganath R. Navalgund, Space Applications Center (India)

Shailesh R. Nayak, Ministry of Earth Sciences (India)

Symposium Technical Program Chairs

Robert J. Frouin, Scripps Institution of Oceanography, University of California, San Diego (United States)

Vaddadi Jayaraman, Indian Space Research Organisation (India)

Kohei Mizutani, National Institute of Information and Communications

Technology (Japan)

Symposium Steering Committee

Upendra N. Singh, Chair, NASA Langley Research Center (United States)

George J. Komar, Cochair, NASA Goddard Space Flight Center (United States)

Kazuhiro Asai, Tohoku Institute of Technology (Japan)

Robert J. Frouin, Scripps Institution of Oceanography, University of California, San Diego (United States)

Jack A. Kaye, NASA Headquarters (United States)

A. S. Kiran Kumar, Space Applications Center (India)

Delu Pan, State Oceanic Administration (China)

Jinxue Wang, Raytheon Company (United States) 
Symposium International Organizing Committee

Yu-Hwan Ahn, Korea Ocean Research \& Development Institute (Korea, Republic of)

Jinyu Cheng, Chinese Society of Oceanography (China)

Adarsh Deepak, Science and Technology Corporation (United States)

Ramesh K. Kakar, NASA Headquarters (United States)

Teruyuki Nakajima, The University of Tokyo (Japan)

Haruhisa Shimoda, Japan Aerospace Exploration Agency (Japan)

Lelia B. Vann, NASA Langley Research Center (United States) 


\title{
Conference Committee
}

\author{
Conference Chairs
}

Allen M. Larar, NASA Langley Research Center (United States)

Hyo-Sang Chung, Chosun University (Korea, Republic of)

Makoto Suzuki, Japan Aerospace Exploration Agency (Japan)

Program Committee

Gail E. Bingham, Utah State University (United States)

Ryoichi Imasu, The University of Tokyo (Japan)

Kyu-Sung Lee, Inha University (Korea, Republic of)

John F. Le Marshall, Bureau of Meteorology (Australia)

Thomas S. Pagano, Jet Propulsion Laboratory (United States)

Jeff Puschell, Raytheon Space \& Airborne Systems (United States)

Henry E. Revercomb, University of Wisconsin-Madison (United States)

William L. Smith, Sr., Hampton University (United States)

Jianyu Wang, Shanghai Institute of Technical Physics (China)

\section{Session Chairs}

$1 \quad$ Atmospheric Sounding, Retrievals, and Information Content

Makoto Suzuki, Japan Aerospace Exploration Agency (Japan)

2 Data Processing, Compression, and Fusion

Ryoichi Imasu, The University of Tokyo (Japan)

3 Remote Sensing Air Quality Applications

Jianyu Wang, Shanghai Institute of Technical Physics (China)

4 Future Sensors: Calibration and Sensor Design

Daniel K. Zhou, NASA Langley Research Center (United States)

$5 \quad$ Remote Sensing Land Applications

Hyo-Sang Chung, Chosun University (Korea, Republic of)

Poster Session

Allen M. Larar, NASA Langley Research Center (United States) 
Downloaded From: https://www.spiedigitallibrary.org/conference-proceedings-of-spie on 26 Apr 2023

Terms of Use: https://www.spiedigitallibrary.org/terms-of-use 


\section{Introduction}

Accurately calibrated multi-, hyper-, and ultraspectral remote sensing measurement systems are rapidly becoming the instruments of choice for observing a wide variety of geophysical variables from ground-, aircraft-, and satellite-based platforms. New data processing and analysis techniques are emerging for the optimum interpretation of resultant radiance measurements obtained by these spectrometer systems, covering a spectral range from the visible to the far infrared, to enable a wide range of research and operational applications; geophysical applications include, for example, surface and cloud property characterizations along with retrievals of atmospheric state, dynamics, and composition, all at high spatial resolution while simultaneously covering large areas. Geophysical remote sensing data products from multi- to ultraspectral remote sensing systems promise to accelerate scientific research on environmental processes, enable efficient monitoring of environmental variables, and lead to improved predictive capability for such parameters and how they respond to natural and anthropogenic external forcings. New and improved technologies and techniques promise smaller and lighter next-generation sensor systems for enhancing current and enabling new future measurement capabilities.

The conference on Multispectral, Hyperspectral, and Ultraspectral Remote Sensing Technology, Techniques, and Applications III was part of SPIE's AsiaPacific Remote Sensing symposium held in Incheon, Republic of Korea, 11-14 October 2010. The objective of the conference was to bring together the scientific, engineering, and data user communities to provide an international forum for exchanging information about the development, application of, and experimental results from multi-, hyper- and ultraspectral resolution remote sensing measurement systems. Primary focus areas were associated with the design, development, and implementation of, as well as analysis and usage of data from, such remote sensing systems intended for environmental monitoring applications. The conference was very successful with approximately 45 oral and poster presentations delivered from authors of diverse international affiliations (i.e., United States, Japan, China, Republic of Korea, Malaysia, Taiwan, Russia, and Canada). The conference presentation structure was composed of five oral sessions and one poster session. Several of the oral presentations had different aspects of their topical areas also covered in the poster session. The first oral session of this conference focused on atmospheric sounding, geophysical parameter retrieval methodology, and information content. The second session addressed data processing, compression, and fusion. The third session concentrated on remote sensing air quality applications, while the fourth session addressed calibration and sensor design for future sensors. The fifth and final oral session focused on remote sensing land applications. 
We would like to express our sincere appreciation to the program committee and session chairs, to colleagues who participated in the conference, to the SPIE staff, and to all our hosts and meeting sponsors in Incheon whose contributions were all essential to the success of this conference.

\section{Allen M. Larar \\ Hyo-Sang Chung Makoto Suzuki}

